\title{
Invasion of Intestinal Cells by Staphylococcus aureus is Mediated by Pyruvate Formate Lyase (Pfl) Protein
}

\author{
Sejeong Kim ${ }^{1,2}\left(\mathbb{D}\right.$, Jiyoon Lee ${ }^{3}$, Soomin Lee ${ }^{1,2} \mathbb{D}$, Jimyeong Ha ${ }^{1,2} \mathbb{D}$, Jeeyeon Lee ${ }^{1,2} \mathbb{D}$, \\ Yukyung Choi ${ }^{1,2}$ (D) Hyemin $\mathrm{Oh}^{1,2}$ (D) , Yohan Yoon ${ }^{1,2 *}$ (D) and Kyoung-Hee Choi ${ }^{4 *}$ (i) \\ ${ }^{1}$ Department of Food and Nutrition, Sookmyung Women's University, Seoul 04310, Korea. ${ }^{2}$ Risk Analysis Research \\ Center, Seoul 04310, Korea. ${ }^{3}$ Center for Food and Bioconvergence, SNU, Seoul 08826, Korea. ${ }^{4}$ Department of Oral \\ Microbiology, College of Dentistry, Wonkwang University, Iksan, Jeonbuk 54538, Korea.
}

\begin{abstract}
Staphylococcus aureus is a known enterotoxin-producing foodborne pathogen; however, the invasion mechanism of the bacterium into intestinal cells remains unclear. The aim of this study was to determine whether $S$. aureus can invade Caco-2 cells, and to elucidate the gene responsible for this invasion. Caco2 cells were infected with S. aureus strains NCCP10862, KACC13236, KACC10768 and KACC11596, and their invasion efficiencies were evaluated. Proteins found in the invasive and noninvasive $S$. aureus strains were labelled with isobaric tags for relative and absolute quantification (iTRAQ), and the gene encoding the protein responsible for $S$. aureus invasion was deleted using a temperature-sensitive plasmid, pIMAY. The Caco- 2 cell invasion efficiencies of the wild type and mutant $S$. aureus were then compared. Among the S. aureus strains, only NCCP10862 and KACC10768 were able to invade Caco2 cells, and these strains had a higher level of pyruvate formate lyase (Pfl) protein expression than that of the noninvasive strains. Therefore, a pflB-deletion mutant of KACC10768 was prepared, which revealed a $60 \%$ decrease in invasion efficiency when compared to the wild type. These results indicate that certain $S$. aureus strains can invade intestinal cells, and the protein encoded by the pfl gene is involved in this invasion.
\end{abstract}

Keywords: Staphylococcus aureus, invasion, pyruvate formate lyase, foodborne pathogen.

*Correspondence: kheechoi@wku.ac.kr; +82 63-850-6911/ yyoon@sookmyung.ac.kr; +82 2-2077-7585

(Received: 11 April 2019; accepted: 06 June 2019)

Citation: Sejeong Kim, Jiyoon Lee, Soomin Lee, Jimyeong Ha, Jeeyeon Lee, Yukyung Choi, Hyemin Oh, Yohan Yoon, and KyoungHee Choi, Invasion of Intestinal Cells by Staphylococcus aureus is Mediated by Pyruvate Formate Lyase Protein (PFLB), J Pure Appl Microbiol., 2019; 13(2): 647-652. doi: 10.22207/JPAM.13.2.01

(c) The Author(s) 2019. Open Access. This article is distributed under the terms of the Creative Commons Attribution 4.0 International License which permits unrestricted use, sharing, distribution, and reproduction in any medium, provided you give appropriate credit to the original author(s) and the source, provide a link to the Creative Commons license, and indicate if changes were made. 


\section{INTRODUCTION}

Staphylococcus aureus, a gram-positive and facultative anaerobic bacterium, is a foodborne pathogen that is a global health threat ${ }^{1}$. S. aureus is generally found on human skin, and when food is exposed to $S$. aureus-laden skin, it can result in food contamination and disease. S. aureus can grow and multiply up to $10^{6} \mathrm{CFU} / \mathrm{g}$ under optimal growth conditions $\mathrm{s}^{2,3}$, and produces endotoxins in the food ${ }^{4,5}$. Staphylococcal foodborne illness is caused by consuming food contaminated with S. aureus enterotoxins (SEs), and symptoms of the illness include vomiting and diarrhea ${ }^{6}$. SES (SEA-SEE, SEG-SEJ, and SER-SET) are heat stable and resistant to low $\mathrm{pH}$. SEA is the most common enterotoxin recovered from foodborne illness outbreaks followed by SED and SEB ${ }^{7,8}$.

Therefore, this bacterium is considered as an enterotoxigenic rather than an invasive infection-causing bacterium. The possibility of $S$. aureus intestinal colonization and its implications on host health were previously reported by Gries et $a l .{ }^{9}$, wherein they suggested that the cecal mucus layer facilitates the intestinal colonization of methicillin-resistant $S$. aureus. Furthermore, Vriens et $a .^{10}$ reported the presence and interaction of $S$. aureus in the rectum of patients in surgical intensive care and liver transplant units. However, the mechanism underlying the intestinal invasion of $S$. aureus remains unclear.

Therefore, this study aimed to determine whether S. aureus can invade human intestinal cells, and to elucidate gene for the invasion.

\section{MATERIALS AND METHODS Inoculum preparation}

Bacterial strains were purchased from National Culture Collection for Pathogens (NCCP; Seoul, Korea) and Korean Agricultural Culture Collection (KACC). Four S. aureus strains, NCCP10862, KACC13236, KACC10768, and KACC11596, were cultured on mannitol salt agar (MSA; Becton, Dickinson and Company, Sparks, $M D, U S A)$ and then inoculated into tryptic soy broth (TSB; Becton, Dickinson and Company). They were incubated at $35^{\circ} \mathrm{C}$ for $24 \mathrm{~h}$. Hundred microliters of the culture was sub-cultured into fresh TSB, followed by incubation at $35^{\circ} \mathrm{C}$ for 24 h. The subcultures were centrifuged at $1912 \mathrm{xg}$ and incubated at $4^{\circ} \mathrm{C}$ for $15 \mathrm{~min}$. Thereafter, the cell pellets were washed twice with phosphate buffered saline (PBS; pH 7.4; $0.2 \mathrm{~g} \mathrm{KH}_{2} \mathrm{PO}_{4^{\prime}} 1.5 \mathrm{~g}$ $\mathrm{Na}_{2} \mathrm{HPO}_{4} \cdot 7 \mathrm{H}_{2} \mathrm{O}, 8.0 \mathrm{~g} \mathrm{NaCl}$, and $0.2 \mathrm{~g} \mathrm{KCl}$ in $1 \mathrm{~L}$ of distilled water), and eventually suspended in 10 $\mathrm{mL}$ of PBS. The suspensions to be inoculated were diluted with PBS to $\mathrm{OD}_{600}=0.01$.

\section{Intestinal cell invasion assay}

The intestinal cell line, Caco-2, was purchased from the Korean Cell Line Bank (Seoul, Korea). The cells were cultured for $72 \mathrm{~h}$ at $37^{\circ} \mathrm{C}$ and $5 \% \mathrm{CO}_{2}$ in Eagle's minimum essential medium (MEM; Gibco, Penrose, Auckland, New Zealand), supplemented with $20 \%$ fetal bovine serum (FBS; Gibco) and $1 \%$ penicillin-streptomycin (PS; Gibco), until the Caco-2 cells formed a monolayer, which was then detached by trypsin. Thereafter, the cells were washed twice with Dulbecco's phosphate buffered saline (DPBS; Welgene, Daegu, Korea), and suspended in MEM supplemented with $20 \%$ FBS. For the invasion assay, diluted Caco-2 cells, at a final concentration of $5.0 \times 10^{4}$ cells $\mathrm{mL}^{-1}$, were placed in 24-well plates and incubated at $37^{\circ} \mathrm{C}$ and $5 \% \mathrm{CO}_{2}$ for $48 \mathrm{~h}$. One milliliter of each $S$. aureus culture was inoculated into the plate and incubated for $2 \mathrm{~h}$ at $37^{\circ} \mathrm{C}$ and $\mathrm{CO}_{2}$ to allow $S$. aureus invasion into Caco- 2 cells. Aliquot of the inoculum was properly diluted in BPW and $100 \mu \mathrm{L}$ of the diluents was spread-plated on TSA plates. Colonies grown on TSA plates were counted after $24 \mathrm{~h}$ of incubation, and the bacterial cell counts were used as initial bacterial cell counts. Planktonic S. aureus cells in the supernatant were discarded, and the attached $S$. aureus cells were treated with gentamicin $\left(50 \mu \mathrm{g} \mathrm{mL}^{-1}\right)$ or PBS for $2 \mathrm{~h}$. The Caco- 2 cell membrane was then lysed using $0.1 \%$ TritonX-100 for $20 \mathrm{~min}$. About $100-\mu \mathrm{L}$ aliquots of the suspensions were spread-plated on TSA, and incubated at $37^{\circ} \mathrm{C}$ for $24 \mathrm{~h}$. The colonies were manually counted to enumerate the invasive $S$. aureus. Invasion efficiency (\%) was calculated as follows: (invaded bacterial cell counts/initial bacterial cell counts) $\times 100$.

Isobaric tags for relative and absolute quantification (iTRAQ) screening for invasionrelated protein

To identify the protein responsible for S. aureus invasion of Caco-2 cells, bacterial cells harvested from 1-1.5 $\mathrm{mL}$ of $S$. aureus culture were lysed by suspension in lysis buffer (iNtRON, Seongnam, Korea) and lysostaphin $\left(0.5 \mathrm{mg} \mathrm{mL}^{-1}\right.$; 
Sigma Aldrich, St. Louis, MO, USA), and incubation at $37^{\circ} \mathrm{C}$ for $2 \mathrm{~h}$. The lysates were then treated with SMART bacterial solution (iNtRON), and centrifuged $(8,000 \mathrm{xg}$ and $5 \mathrm{~min})$. Proteins in the supernatants were stored at $-80^{\circ} \mathrm{C}$ until used. The proteins were precipitated using acetone at $-20^{\circ} \mathrm{C}$. After acetone was then removed by vaporization, the precipitated proteins were resuspended in urea buffer $\left(50 \mathrm{mmol} \mathrm{I}^{-1}\right.$ Tris $\mathrm{pH}$ 8.3, $3 \mathrm{M}$ urea), and digested by trypsin (1:10) at $37^{\circ} \mathrm{C}$ for $16 \mathrm{~h}$. The digested proteins were labeled with the iTRAQ reagent suspended in isopropanol (Global standard; GS-113, 10862-116, 13236-117, 10768-119, and 11596-121) for $1 \mathrm{~h}$ at $25^{\circ} \mathrm{C}$, and then, completely dried in a SpeedVac centrifuge. The labeled samples were fractionated using cation exchange chromatography on Agilent 1100 system (Agilent Technologies, Santa Clara, CA, USA), and analyzed using LC-MS/MS with a hybrid quadrupole-TOF LC-MS/MS spectrometer (Applied Biosystems, Foster City, CA, USA). Peptides and proteins were then identified and quantified using the ProteinPilot Software 2.0.1 (Applied Biosystems), and differences in protein expression among the $S$. aureus strains were analyzed.

\section{Gene mutation}

iTRAQ data revealed that the invasive $S$. aureus had a higher level of pyruvate formate lyase expression (Pfl) than that of the noninvasive strain. Thus, a pflB deletion mutant was constructed as described by Lee et al. ${ }^{11}$. Table 1 lists the bacterial strains, primers, and plasmids used in this study.

Table 1. Bacterial strains, plasmids, and primers used in this study

\begin{tabular}{|c|c|c|}
\hline Strains & Description & Reference \\
\hline E. coli DC10B & High efficiency cloning strain & Monk et al. ${ }^{12}$ \\
\hline Plasmid & E. coli $\mathrm{DH} 10 \mathrm{~B}(\mathrm{dcm}-)$ & \\
\hline pIMAY & $\begin{array}{l}\text { E. coli-S. aureus shuttle vector, } \\
\text { temperature- sensitive }\end{array}$ & Monk et al. ${ }^{12}$ \\
\hline pIMAY-pflB $B_{\text {trunc }}$ & pIMAY ligated with truncated $p f l B$ & This study \\
\hline Primer & Sequence $\left(5^{\prime} \rightarrow 3^{\prime}\right)$ & \\
\hline pflB-F(Pstl) & GGA ACA AGT ACT GCA GTT ATC GAA & This study \\
\hline pflB-R(Sall) & TGT TAA CTG TCG ACA TTC TTC TGG & This study \\
\hline pflB'-F & TAA GCC GTC CAG CAG AAA & This study \\
\hline pfli $B^{\prime}-R$ & CCG TAT ACA ACG TTT GAA G & This study \\
\hline
\end{tabular}

\section{Construction of pIMAY-pflB $B_{\text {trunc }}$}

Chromosomal DNA of wild type invasive strain was extracted using DNeasy Blood and Tissue Kit (Qiagen, Hilden, Germany), and was used as template for following PCR amplification. The $p f l B$ gene was amplified using pflB-F (Pstl) and pflB-R (Sall) primers with PCR conditions as follow; $95^{\circ} \mathrm{C}-5 \mathrm{~min}, 35 \mathrm{cycles}$ of $95^{\circ} \mathrm{C}-30 \mathrm{sec}$, $43^{\circ} \mathrm{C}-30$ sec and $72^{\circ} \mathrm{C}-1 \mathrm{~min}$, and $72^{\circ} \mathrm{C}-5 \mathrm{~min}$. After the amplified $p f l B$ was purified with QIAquick gel extraction kit (Qiagen), the gene was digested with EcoRV (Elpisbio, Daegen, Korea), which targets two sites (900 bp distance) of the pflB gene. The digested $p f l B$ fragments were self-ligated with DNA ligation kit (Takara, Shiga, Japan) to form truncated pflB. The truncated $p f l B$ and pIMAY that was a shuttle vector were then digested by restriction enzymes, Pstl and Sall, and the two DNA fragments were ligated by the DNA ligation kit to produce

$$
\text { pIMAY-pflB }{ }_{\text {trunc }} \text {. }
$$

Transformation and cloning in E. coli DC10B pIMAY-pflB ${ }_{\text {trunc }}$ was transformed into high-efficiency cloning strain, E. coli DC10B as described by Monk et al. ${ }^{12}$. Briefly, competent $E$. coli $\mathrm{DC} 10 \mathrm{~B}$ cells were prepared using a chemical method ${ }^{13}$, and stored in $-80^{\circ} \mathrm{C}$ deep freezer until used. The competent cells were mixed with pIMAY-pfIB $B_{\text {trunc }}$ in microcentrifuge tube on ice, and the transformation was induced by heatshock at $42^{\circ} \mathrm{C}$ for $30 \mathrm{sec}$. The transformants were spread-plated on LB agar containing $15 \mu \mathrm{g} \mathrm{m}^{-1}$ of chloramphenicol $(\mathrm{Cm})$. The plates were then incubated at $37^{\circ} \mathrm{C}$ for $24 \mathrm{~h}$ to obtain E. coli DC10B containing pIMAY- $p f l B_{\text {trunc }}$.

\section{Electroporation and allelic exchange} pIMAY-pflB ${ }_{\text {trunc }}$ was extracted from the $E$. coli DC10B with DNA Plasmid SV kit (GeneAll, Seoul, Korea) according to the manufacturer's protocol. 
pIMAY-pflB $B_{\text {trunc }}$ was precipitated using ethanol, and the plasmid DNA was then transformed into $S$. aureus by electroporation. To induce single-crossover integration, the $S$. aureus strain containing pIMAY-pflB $B_{\text {trunc }}$ was grown at $37^{\circ} \mathrm{C}$ for $24 \mathrm{~h}$ in LB broth containing $\mathrm{Cm}\left(15 \mu \mathrm{g} \mathrm{mL} \mathrm{m}^{-1}\right)$. The culture was streaked on LB agar $+\mathrm{Cm}$, and incubated at $37^{\circ} \mathrm{C}$ for $24 \mathrm{~h}$. One $S$. aureus colony from the agar was then cultured in LB broth without $\mathrm{Cm}$ at $28^{\circ} \mathrm{C}$, followed by streaking on LB agar containing $1 \mu \mathrm{g} \mathrm{mL}^{-1}$ of anhydrotetracycline (ATC) to induce excitation of remained plasmid fragment. Eventually, the colony was dually streaked on LB agar containing $A T c$ and $\mathrm{Cm}$. The object grown only on LB agar+ATC not on LB agar+Cm was considered as a mutant $S$. aureus strain which contained truncated $p f l B$ instead of original $p f l B^{11}$. Existence of $p f l B_{\text {trunc }}$ on $S$. aureus genome was eventually confirmed by DNA sequencing and PCR analysis using pflB'-F and pflB'-R primers, which were created from sequences lying outside the truncated pflB (Cosmogenetech, Seoul, Korea). DNA sequencing was analyzed using BigDye ${ }^{\mathrm{TM}}$ Terminator v3.1 Cycle Sequencing kit and 373 DNA Analyzer (Applied Biosystems). The lengths of $p f l B$ in wild- (2,250 bp) and mutant-type (1,350 bp) strains were compared.

\section{Statistical analysis}

The experiments were repeated twice, and two samples were used in each replication ( $n$ $=4)$. Because the replication had random effects on a dependent variable ( $S$. aureus invasion efficiency), a mixed procedure of SAS ${ }^{\bullet}$ (Version 9.2, SAS Institute, Cary, NC, USA) was used to analyze the results, and the least squares means of the invasion efficiency among $S$. aureus strains were then compared, using pairwise $t$-test at $\alpha=0.05$.

\section{RESULTS AND DISCUSSION}

The invasion efficiencies of the $S$. aureus strains were compared. Among the afore- mentioned strains, S. aureus strains NCCP10862 and KACC10768 showed Caco-2 cell invasion (36.3\%-38.4\%), but the other strains showed no cellular invasion (Fig. 1). These two strains were clinical isolates, and S. aureus KACC10768 was identified as a methicillin-susceptible strain. These strain-variation was also shown in other studies. Blevins et al. ${ }^{14}$ showed that regulatory roles of sarA and agr, which control virulence factors in S. aureus, were strain-dependent. Belkum and Melles ${ }^{15}$ also presented the strain variation of S. aureus strains in pathogenicity. To elucidate the strain variation of $S$. aureus in Caco- 2 cell invasion, the proteins profiles of $S$. aureus strains NCCP10862 and KACC10768 were screened using iTRAQ. The results indicated that $\mathrm{Pfl}$ protein expression was upregulated in the invasive $S$. aureus strains, followed by an increase in the levels of elongation factor Tu and phosphopyruvate hydratase in the strains (Table 2). The elongation factor Tu and phosphopyruvate hydratase genes were not subjected to mutation because they are essential for $S$. aureus survival. Thus, only $p f l B$ gene was subjected to the mutation.

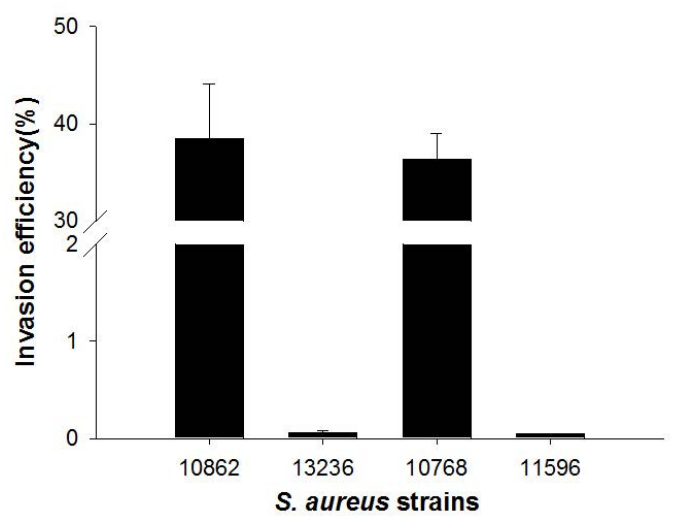

Fig. 1. Comparison of Caco-2 cell invasion efficiencies for Staphylococcus aureus strains NCCP10862, KACC13236, KACC10768, and KACC11596.

Table 2. Relative protein quantification of Staphylococcus aureus strains. 113-Global Standard (GS), 116: S. aureus NCCP10862, 117: S. aureus KACC13236, 119: S. aureus KACC10768, 121: S. aureus KACC11596

\begin{tabular}{lccc}
\hline Name & $116: 113$ & $117: 113$ & $119: 113121: 113$ \\
\hline $\begin{array}{l}\text { Elongation } \\
\text { factor Tu }\end{array}$ & 0.4105 & 0.8765 & 5.20070 .7146 \\
$\begin{array}{l}\text { Phosphopyruvate } \\
\text { hydratase }\end{array}$ & 0.8292 & 0.7503 & 2.75680 .7573 \\
\hline
\end{tabular}


To elucidate the role of $\mathrm{Pfl}$ in $S$. aureus invasion, the $p f B$ mutant of $S$. aureus was prepared. The truncated $p f l B(C a .900 \mathrm{bp}$ ) was constructed by EcoRV. The truncated construct and pIMAY were cut with the same restriction enzymes, ligated, and transformed into $E$. coli DC10B. The pIMAY-pflB trunc was then transformed into $S$. aureus through electroporation, integrated into the chromosome, and the $S$. aureus pflB mutation was confirmed through PCR. Compared to the wild-type, the invasion efficiency of the mutant strain into the Caco- 2 cells decreased by $60 \%(p<0.05)$ (Fig. 2). This result indicates that, although $\mathrm{Pfl}$, known as an oxygen sensitive enzyme, was involved in the conversion of pyruvate to formate, it is crucial for $S$. aureus invasion into Caco-2 cells (Fig. 2). In a previous study, it was proved that pflB had important role in deeper layer of biofilm formation as Pfl supplies formate on such anaerobic and nutrient-deficient conditions ${ }^{16}$. Biofilm formation and adhesion are usually first step of $S$. aureus infection for persistence of bacteria in host, and the colonization and persistence on around of the invaded cells is probably important in the invasion procedure of bacterial cells. Taken together, it can be suggested that $p f l B$ may have a role in the intestinal cell invasion of $S$. aureus in the process of biofilm formation.

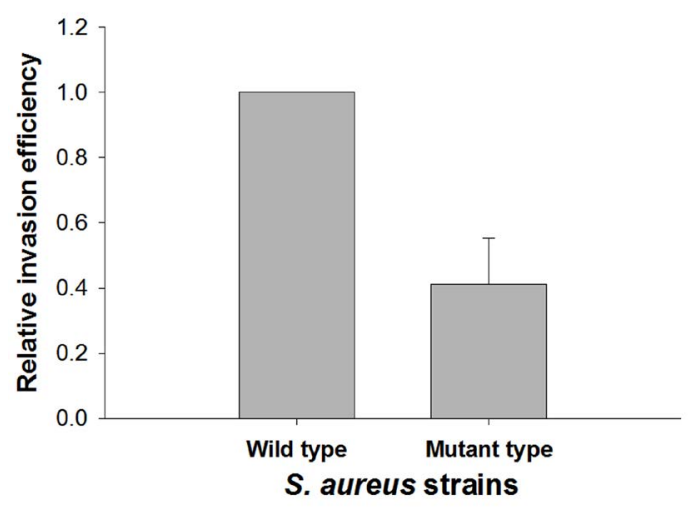

Fig. 2. Relative invasion efficiencies of the $p f l B$ mutant to wild type Staphylococcus aureus KACC10768.

\section{CONCLUSION}

In conclusion, although $S$. aureus is known to cause foodborne illness by release of toxins, and the mechanism of intestinal cell invasion remains unclear, certain $S$. aureus strains can invade the intestinal cells due to the expression of the $p f l$ gene. Thus, the chronic effect of invasive $S$. aureus in the intestine should be further researched.

\section{ACKNOWLEDGEMENTS}

pIMAY and E. coli DC10B used for $S$. aureus gene mutation was kindly provided by Monk et al. ${ }^{12}$.

\section{CONFLICTS OF INTEREST}

The authors declare that there are no conflicts of interest.

\section{AUTHORS' CONTRIBUTION}

All authors listed have made a substantial, direct and intellectual contribution to the work, and approved it for publication.

\section{FUNDING}

This study was supported by Wonkwang university in 2018.

\section{DATA AVAILABILITY}

All datasets generated or analyzed during this study are included in the manuscript and/or the Supplementary Files.

\section{ETHICS STATEMENT}

This article does not contain any studies with human participants or animals performed by any of the authors.

\section{REFERENCES}

1. EFSA. Assessment of the public health significance of methicillin resistant Staphylococcus aureus (MRSA) in animals and foods - scientific opinion of the panel on biological hazards. EFSA Journal, 2009; 993: 1e73.

2. Foster T., Staphylococcus. In Baron S. Galveston (eds.), Medical Microbiology, $4^{\text {th }}$ Ed. University of Texas Medical Branch at Galveston, 1996.

3. Lowy F.D. Staphylococcus aureus infections. New Engl. J. Med., 1998; 339: 520-532.

4. Novick R.P., Pathogenicity factors and their regulation. ASM Press, Washington, D.C., 2000.

5. Kim J.H., Yoo J.G., Ham J-S., Oh M-H. Direct Detection of Escherichia coli, Staphylococcus aureus, and Salmonella spp. In animal-derived foods using a magnetic bead-based immuno-assay. Korean J. Food Sci. An., 2018; 28: 727-736.

6. Argudin M.A., Mendoza M.C., Rodicio M.R. Food poisoning and Staphylococcus aureus entero-toxins. Toxins, 2010; 2: 1751-1773.

7. Schmid D., Fretz R., Winter P., Mann M., HY ger G., Styger A., Ruppitsch W., Ladstitter J., 
Mayer N., de Martin A., Allerberger F. Outbreak of staphylococcal food intoxication after consumption of pasteurized milk products, June 2007, Austria. Wien Klin Wochenschr., 2009; 121:125-131.

8. Veras J.F., do Carmo L.S., Tong L.C., Shupp J.W., Cummings C., Dos Santos D.A., Cerqueira M.M., Cantini A., Nicoli J.R., Jett M. A study of the enterotoxigenicity of coagulase-negative and coagulase-positive staphylococcal isolates from food poisoning outbreaks in Minas Gerais, Brazil. Int. J. Infect. Dis., 2008; 12:410-415.

9. Gries D.M., Pultz N.J., Donskey C.J. Growth in cecal mucus facilitates colonization of the mouse intestinal tract by methicillin-resistant Staphylococcus aureus. J. Infect. Dis., 2005; 192: 1621-1627.

10. Vriens M.R., Fluit A.C., Troelstra A., Verhoet J., Werken C. Staphylococcus aureus rectal carriage and its association with infections in patients in a surgical intensive care unit and a liver transplant unit. Infect. Control Hosp. Epidemiol., 2014; 23: 495-501.

11. Lee S., Kim S., Lee H., Ha J., Lee J., Choi Y., Oh H., Yoon Y., Choi K.H. icaA gene of Staphylococcus aureus responds to $\mathrm{NaCl}$, leading to increased biofilm formation. J. Food
Prot., 2018; 81: 412-416.

12. Monk I.R., Shah I.M., Xu M., Tan M-W., Foster T.J. Transforming the untransformable: application of direct transformation to manipulate genetically Staphylococcus aureus and Staphylococcus epidermidis. mBio, 2012; 3: e00277-11.

13. Tu Z., He G., Li K.X., Chen M.J., Chang J., Chen L. et al. An improved system for competent cell preparation and high efficiency plasmid transformation using different Escherichia coli strains. J. Biotechnol., 2005; 8: 113-120.

14. Blevins J.S., Beenken K.E., Elasri M.O., Hurlburt B.K., Smeltzer M.S. Strain-dependent differences in the regulatory roles of sarA and agr in Staphylococcus aureus. Infect. Immun., 2002; 70: 470-480.

15. Van Belkum A., Melles D.C. Not All Staphylococcus aureus strains are equally pathogenic. Discov. Med., 2009; 5: 148-152.

16. Leibig M., Liebeke M., Mader D., Lalk M., Peschel A., Gotz F. Pyruvate formate lyase acts as a formate supplier for metabolic processes during anaerobiosis in Staphylococcus aureus. J. Bacteriol., 2011; 193: 952-962. 